\title{
PENYESUAIAN DIRI PADA PASANGAN PERJODOHAN DI KAMPUNG MADURA
}

\section{SELF-ADJUSTMENT IN ARRANGED MARRIAGE COUPLES IN MADURA VILLAGE}

\author{
Asri Khuril Aini ${ }^{1}$, Fathul Lubabin Nuqul ${ }^{2}$ \\ ${ }^{1}$ Polres Malang Jawa Timur, Malang, Indonesia \\ ${ }^{2}$ Universitas Islam Negeri Maulana Malik Ibrahim, Malang, Indonesia \\ email: asrikhurilaini10@gmail.com¹, lubabin_nuqul@uin-malang.ac.id ${ }^{2}$
}

\begin{abstract}
ABSTRAK
Penelitian ini bertujuan untuk mengetahui proses dan problem dalam perjodohan, potensi kekerasan yang dialami oleh pasangan serta pola solusi dalam mengatasi masalah pasangan yang dijodohkan. Metode penelitian yang digunakan yaitu metode penelitian kualitatif dengan pendekatan fenomenologis. Teknik pengumpulan data menggunakan teknik wawancara. Subyek penelitian tersebut dipilih secara purposif (purposive sampling) yaitu dipilih berdasarkan ciri-ciri tertentu maksimal usia pernikahan satu tahun dan menikah dengan sistem dijodohkan. Penelitian ini melibatkan tiga pasangan suami istri yang menikah dengan sistem perjodohan. Hasil penelitian ini menjelaskan bahwa proses penyesuaian diri pada pasangan yang dijodohkan memiliki jangka waktu yang berbeda-beda. Berdasarkan data di lapangan penyesuaian diri pada pihak mempelai pria lebih singkat berbeda dengan jangka waktu pada mempelai wanita yang membutuhkan waktu cukup lama dalam penyesuaian diri. Proses penyesuaian diri yang terlibat bukan hanya pada kedua belah pihak saja akan tetapi keluarga dan lingkungan juga turut andil dalam proses penyesuaian diri. Pasangan menyesuaikan diri dengan cara tetap menjalin komunikasi yang baik, terbuka, saling menghargai, menjaga perasaan pasangan, menghormati dan berdiskusi untuk menyelesaikan permasalahan yang dihadapi dan akhirnya pasangan tersebut berhasil menyesuaikan diri dengan baik.
\end{abstract}

Kata Kunci: Penyesuaian Diri, Perjodohan, Keluarga.

\section{ABSTRACT}

This study aims to determine the processes and problems in arranged marriages, the potential for violence experienced by couples and the pattern of solutions in overcoming the problems of paired couples. The research method used is a qualitative research method with a phenomenological approach. Data collection techniques are using interview techniques. The research used purposive that are chosen based on specific characteristics, namely a maximum age of one year of marriage and marriage to the matched system. This study involved three married couples who were married to the matchmaking system. The results of this study explain that the process of adjustment in an arranged marriage partner has different periods, from the data in the field of adjustment on the groom's shorter period is different from the period on the bride who needs a long time in adjustment. The adjustment process involved is not only on both sides but also the family, and the environment also contributes to the adjustment process. The couple adjusts to a way to stay in excellent communication, open, mutual respect, maintain the feelings of the couple, respect and discuss to solve the problems faced and finally the couple managed to adjust well.

Keywords: Self Adjusment, Arranged Marriage, Family.

\begin{tabular}{|c|c|c|c|}
\hline First Received: & Revised: & Accepted: & Published: \\
30 September 2019 & 03 October 2019 & 04 October 2019 & October 2019 \\
\hline
\end{tabular}




\section{PENDAHULUAN}

Memilih pasangan hidup merupakan suatu hal yang sangat sensitif karena berkaitan langsung dengan unsur vital manusia yaitu perasaan. Tidak hanya itu memilih pasangan bukan soal hari ini saja, namun harus memikirkan masa depan, karena pasangan merupakan seseorang yang akan menemani sampai akhir hayat. Salah satu cara pasangan di anggap sah yaitu apabila keduanya telah terikat pada janji pernikahan. Dewanti (2012) menyebutkan bahwa terdapat dua jenis pernikahan, yaitu pernikahan atas dasar cinta dan pernikahan yang diatur oleh kerabat atau orang tua yang disebut perjodohan. Novitasari (2013) menjelaskan bahwa di Indonesia tradisi perjodohan ternyata masih di pertahankan, khusunya di daerah Jawa Timur. Salah satu daerah yang masih kental dengan sistem perjodohan terjadi di Kampung Madura Desa Jambearjo Kecamatan Tajinan. Peran orang tua tidak pernah luput dari keputusan memilih jodoh. Hampir seluruh warga masyarakat di Kampung Madura merupakan hasil perjodohan antar orang tua satu dengan orang tua yang lain.

Menurut hasil wawancara pertamakali pada tanggal 28/09/18 pada tokoh masyarakat peristiwa perjodohan sudah berlangsung cukup lama. Bahkan di era perkembangan zaman dengan munculnya berbagai macam alat elektronik yang memperpermudah individu dalam menjalin komunikasi tak memadamkan peristiwa perjodohan di Kampung Madura sampai saat ini. Setiawan (2018) menjelaskan bahwa kemajuan tekhnologi mampu menjangkau seluruh lapisan masyarakat dalam berinteraksi.Seiring dengan perkembangan zaman yang semakin modern dan penuh dengan ragam sosial media seperti facebook, instagram, twitter, whatsApp, serta beragam bentuk kecanggihan teknologi seperti handphone, laptop, dan lainlain. Masyarakat telah dimudahkan untuk melakukan proses interaksi menggunakan komunikasi yang ada di media sosial sehingga dengan mudah mengenal orang-orang di luar daerah, luar kota, bahkan mancanegara melalui jejaring sosial yang digunakan.

Berdasarkan jumlah data yang ada hampir seluruh warga masyarakat Kampung Madura menikah dengan pasangan yang berasal dari Kampung Madura sendiri. Begitu juga dalam wawancara kepada salah satu tokoh masyarakat mengungkapkan bahwa pernikahan dengan sistem endogami ada sejak zaman dahulu dengan alasan bahwa orang tua telah mengetahui bibit, bebet, dan bobot orang yang akan dijodohkan dengan anaknya (W.AJ.14). Eratnya kebudayaan di tengah perkembangan zaman inilah yang menyebabkan peneliti ingin mengetahui proses perjodohan di kampung madura bermula hingga proses pernikahan tersebut dilangsungkan. Sementara itu, calon mempelai sama sekali tidak diberi kewenangan untuk memilih calon pasangan sesuai kriterianya. Peneliti ingin mengetahui bagaimana proses penyesuaian diri pada kedua mempelai meskipun memiliki kriteria atau minat tersendiri dalam memilih calon pasangan namun pada akhirnya mereka tetap konform dengan kebudayaan di sekitarnya dengan menerima pasangan yang bukan pilihannya. 
Konformitas merupakan tendensi untuk mengubah keyakinan dan perilaku seseorang agar sesuai dengan lingkungan kebudayaannya (Taylor, 2009). Dalam tataran kehidupan berumah tangga kemampunya menyesuaikan dengan norma lingkungan terkait dengan proses pasangan tersebut menumbuhkan rasa suka. Lebih lanjut rasa suka akan muncul apabila antara harapan dan kenyataan sesuai (Nuqul, 2009).

Sebelum mengambil sebuah keputusan menikah dengan pilihan orang tua calon pasangan pengantin akan dihadapkan pada beberapa pilihan, apakah dia akan tetap mempertahankan pilihannya atau menuruti keinginan orang tua. tidak hanya dalam memilih pasangan, dalam sebuah kehidupan setiap orang seringkali dihadapkan pada banyak pilihan yang kemudian berujung pada pengambilan keputusan. Sebelum benar-benar mengambil keputusan, individu pasti menghadapi proses yang panjang dalam mempertimbangkan dan menentukan pilihannya. Pengambilan keputusan bukanlah hal yang mudah karena keputusan yang telah diambil merupakan suatu hal yang harus di pertanggung-jawabkan dan menjadi konsekuensi panjang bagi setiap individu yang memilih. Eko (2011) menjelaskan bahwa inti dari pengambilan keputusan sendiri adalah terciptanya suatu hasil yang baik, termasuk dalam perjodohan.

Permasalahnnya data menyebutkan bahwa tingkat perceraian yang terjadi di Indonesia kian tahun kian meningkat. Pada Kabupaten Malang terdapat 6.752 kasus perceraian pada tahun 2017 dan berada di urutan ketiga terbesar setelah Kabupaten Ciamis dan Kabupaten Indramayu (Nana, 2018) yang mana disebabkan oleh faktor yang beragam. Salah satu penyebab kedua belah pihak memilih untuk berpisah dengan alasan tidak adanya rasa sayang yang tumbuh diantara keduanya karena pasangan tersebut menikah hanya untuk menuruti perintah orang tua sehingga mereka hanya bisa patuh dan bahtera rumah tangga yang dibangun tidak harmonis dan berujung pada perceraian (Yulianto, 2018). Hal ini sejalan dengan penelitian Fadhilah (2013) dijelaskan bahwa perjodohan merupakan salah satu faktor terjadinya sebuah perceraian.

Padahal pernikahan bukan mengenai legalisasi seks, akan tetapi hubungan yang baik dan komitmen setiap pasangan merupakan hal yang paling penting. Meinarno (2009) menyatakan pernikahan merupakan komitmen antara kedua belah pihak dengan mengadakan pesta pernikahan sehingga secara sosial telah diakui bahwa pasangan tersebut telah menikah. Sementara itu, Atwater \& Duffy (dalam Ardhianita, 2012) menyatakan bahwa kebahagian perkawinan tergantung pada kedua pasangan dalam menyesuaikan diri dalam kehidupan barunya, yaitu saat pasangan memasuki kehidupan perkawinan, seberapa baik mereka menyesuaikan diri dengan pasangannya.

Sejalan dengan fenomena yang terjadi di Kampung Madura, bahwa hampir seluruh masyarakat yang dijodohkan dan melaksanakan pernikahan mampu mempertahankan kehidupan rumah tangga sampai akhir hayat. Artinya sebagian besar masyarakatnya mampu menyesuaikan diri dengan baik meskipun di awal pernikahan antara harapan dan realita tidak sesuai. Namun, banyak dari pasangan di Kampung Madura yang berhasil membangun bahtera rumah tangga dengan baik, tak satupun dari 
pasangan tersebut gagal dalam merajut keluarga baru.

Berdasarkan pemaparan di atas, selain ingin mengetahui proses penyesuaian diri pada pasangan perjodohan ditinjau dari jenis kelamin, peneliti ingin mengetahui faktorfaktor apa yang membuat pasangan tetap menjaga keutuhan rumah tangga dalam menghadapi lika-liku kehidupan terutama pernikahan. Selain itu peneliti juga ingin mengetahui pengendalian konflik serta potensi resiko pada pasangan yang di jodohkan.

\section{METODE PENELITIAN}

Penelitian ini dilakukan dengan menggunakan metode kualitatif dengan pendekatan fenomenologis. Studi fenomenologis mendeskripsikan pemaknaan umum dari sejumlah individu terhadap berbagai pengalaman individu tersebut, dan biasanya difokuskan untuk mendeskripsikan apa yang sama dari pengalaman individu (Creswell, 2015). Dalam pendekatan fenomenologi hal yang diburu adalah esensi dari fenomena yang terjadi. Tujuan utama dari studi fenomenologis untuk mereduksi pengalaman individu yang khas dengan mengidentifikasi fenomena yang terjadi dalam konteks ini penyesuaian diri pada individu yang dijodohkan. Peneliti menggali data dari setiap individu mengenai pengalaman kemudian dikumpulkan dan dikembangkan menjadi sebuah deskripsi.
Deskripsi ini terdiri dari "apa" yang dialami oleh individu dan "bagaimana" individu tersebut mengalami (Moustakas dalam Creswell, 2015).

Teknik sampling yang digunakan yaitu snowball sampling merupakan teknik sampling yang biasa disebut dengan teknik sampling bola salju, penelusuran biasanya bersifat sambung-menyambung hingga pada sasaran (Herdiansyah, 2015). Pada situasi tertentu jumlah subyek penelitian yang terlibat menjadi bertambah untuk mendapatkan akses kepada sumber atau subyek yang hendak diteliti. Kemudian peneliti mencoba menghubungi partisipan yang terpilih untuk melakukan wawancara secara mendalam.

Subyek pada penelitian ini terdiri dari pasangan suami istri yang menikah dengan sistem dijodohkan di Desa Jambearjo Kecamatan Tajinan Kabupaten Malang dengan usia pernikahan maksimal satu tahun. Partisipan tersebut dipilih secara purposif (purposive sampling) berdasarkan kepada ciri-ciri yang sesuai dengan tujuan penelitian, yaitu warga masyarakat Kampung Madura Desa Jambearjo yang menikah dengan sistem perjodohan dan usia pernikahan tidak lebih dari satu tahun. Akhirnya, terdapat tiga pasangan suami istri yang memenuhi kriteria dan diwawancarai lebih lanjut oleh peneliti. Untuk mempermudah peneliti sajikan dalam bentuk tabel berikut. 
Tabel.1

Deskripsi Pasangan Responden Utama

\begin{tabular}{|c|c|c|c|c|c|c|}
\hline & Inisial & Umur & Status & $\begin{array}{c}\text { Jenis } \\
\text { Kelamin }\end{array}$ & Pendidikan & $\begin{array}{c}\text { Lama } \\
\text { Menikah }\end{array}$ \\
\hline \multirow[t]{2}{*}{ Pasangan 1} & M & 31 th & Suami F.N. & Laki-laki & SMP & \multirow{2}{*}{11 Bulan } \\
\hline & F.N & 17 th & Istri M & Perempuan & SMP & \\
\hline \multirow[t]{2}{*}{ Pasangan 2} & H.S & 37 th & Suami N.H & Laki-laki & SMA & \multirow{2}{*}{9 Bulan } \\
\hline & N.H & 28 th & Istri H.S. & Perempuan & SMA & \\
\hline Pasangan 3 & $\begin{array}{l}\mathrm{S} \\
\mathrm{L}\end{array}$ & $\begin{array}{l}28 \text { th } \\
18 \text { th }\end{array}$ & $\begin{array}{l}\text { Suami L } \\
\text { Istri S }\end{array}$ & $\begin{array}{l}\text { Laki-laki } \\
\text { Perempuan }\end{array}$ & $\begin{array}{l}\text { SD } \\
\text { SMP }\end{array}$ & 1 Tahun \\
\hline
\end{tabular}

Tabel 2.

Identitas Responden

\begin{tabular}{cccccc}
\hline No & Nama & Umur & Status & $\begin{array}{c}\text { Jenis } \\
\text { Kelamin }\end{array}$ & Pend \\
\hline 1 & A & 49 th & Kyai & Laki-laki & SMP \\
\hline 2 & J & 51 th & Tetua & Laki-laki & SMP \\
\hline 3 & R & 36 th & Ahli & Perempuan & S2 \\
\hline 4 & W & 20 th & Tetangga L & Perempuan & SMA \\
\hline 5 & F.N & 23 th & Tetangga F.N & Perempuan & SMA \\
\hline
\end{tabular}

Guna melangkapi data penelitian, peneliti melibatkan lima orang diantaranya adalah dua orang sesepuh (tetua) dan tokoh masyarakat di Kampung Madura Desa Jambearjo Kecamatan Tajinan, sahabat dan tetangga subyek, serta satu orang ahli. Pemanfaatan informan bagi peneliti menurut Bogdan \& Biken (dalam Meleong, 2007) informan dimanfaatkan untuk bertukar pikiran dan membandingkan serta meng-crosscheck kejadian yang diperoleh dari sumber atau subjek penelitian.

\section{HASIL DAN PEMBAHASAN}

\section{Potensi Resiko pada Pasangan Perjodohan}

Perjodohan merupakan tindakan penyatuan antara pihak laki-laki dan pihak perempuan, tanpa memperhatikan pihak yang bersangkutan dengan sedikit unsur pemaksaan. Akibat tindakan tersebut banyak pihak yang dijodohkan merasa berat dalam melaksanakan kewajibannya sebagai suami atau istri. Bahkan ada juga subyek yang terpaksa. Keterpaksaan tersebut akan menjadi beban dalam kehidupan individu. Ada beberapa potensi resiko dari adanya sistem perjodohan, yaitu belum siap menjalani bahtera rumah tangga, masih memiliki hubungan dengan pacar sedangkan orang tua tidak setuju, bahkan hubungan pernikahan tidak berlangsung lama.

Pasangan yang dijodohkan belum siap menjalani bahtera rumah tangga. Sebab-sebab ketidaksiapan adalah pertama, belum pernah interaksi sama sekali sebelumnya. Dalam sistem perjodohan kebanyakan tidak pernah ada pertemuan di antara pihak calon mempelai laki-laki dan perempuan. Biasanya mereka baru bertemu setelah prosesi akad selesai. Seseorang yang belum pernah berinteraksi dan bertemu sebelumnya hanya menerka tentang calon pasangannya (W.FN.17). Kedua, adanya kesulitan menyesuaikan diri. Setiap individu saat melakukan sesuatu yang baru dan bertemu dengan orang baru tentunya akan menyesuaikan diri, ikatan yang kurang erat, merasa canggung dan tidak adanya rasa suka 
akan mempersulit dalam proses penyesuaian diri (W.FN.26).

Ketiga, memiliki hubungan dengan pacar. Memiliki hubungan dengan pacar merupakan kunci ketidak-berhasilan dalam membangun rumah tangga, akan tetapi pada masyarakat kampung Madura yang sebelumnya telah memiliki pacar tidak berani menghubungi kembali sebab takut kepada kedua orag tua nya (W.FN.12).

Beberapa penyebab yang menjadi kendala pada pasangan yang dijodohkan diatas umumnya lebih pada kesiapan dan kematangan emosi dalam memasuki rumah tangga. Salah satu bentuk persiapan adalah komitmen dalam menjaga kelangsungan hubungan perkawinan. Ada perbedaan bentuk komitmen antara suami dan istri, suami lebih karena komitmen rasional sedangkan istri lebih termotivasi karena komitmen emosional (Afrida \& Andromeda, 2017). Perbedaan valensi komitmen ini perlu dikomunikasikan dan diatasi maka kemampuan pasangan dalam menyesuaikan diri sangatlah diperlukan dengan tetap menjalin komunikasi dengan baik, saling menghargai, dan saling mempercayai merupakan kunci utama dalam menyesuaikan diri.

\section{Proses Penyesuaian Diri pada Pasangan Perjodohan}

Perjodohan merupakan model pernikahan berupa pengantin wanita atau pengantin pria dipilihkan oleh pihak ketiga seperti orang tua, paman, saudara, bahkan ustadz atau guru. Pernikahan dengan sistem perjodohan sebenarnya tidak ada unsur paksaan. Perjodohan hanya mempertemukan kedua belah pihak yang sebelumnya tidak saling kenal dan dalam proses pengambilan keputusan selanjutnya diserahkan kepada yang berwenang, yakni kedua pasangan yang dijodohkan. Namun masih banyak temuan di lapangan bahwa subyek yang menikah dengan sistem perjodohan rata-rata ada unsur pemaksaan dari pihak ketiga, yaitu orang yang menjodohkan.

Perjodohan sudah menjadi tradisi turuntemurun bagi masyarakat di Kampung Madura Desa Jambearjo Kecamatan Tajinan Kabupaten Malang. Meski sistem perkawinan dengan cara dijodohkan sudah mulai berkurang (W.AJ.15). Namun, tidak bisa dipungkiri bahwa sebagian besar masyarakat di Kampung Madura Desa Jambearjo masih menerapkan model perkawinan dengan sistem Perjodohan. Ada beberapa faktor yang mempengaruhi subyek dalam memilih pasangan, yaitu kebudayaan yang sama, sikap dan perilaku. DeGenova (2008) menyebutkan faktor yang mempengaruhi perilaku memilih latar belakang keluarga di antaranya ras, suku, sosial ekonomi, dan karakteristik personal di antaranya perilaku, sikap, dan kebiasaan.

Orang tua melakukan perjodohan kepada anak mereka disebabkan kekhawatiran orangtua bahwa sang anak akan mendapat pendamping yang tidak bertanggung jawab, serta takut apabila orang tua meninggal mereka tidak mendapat kiriman doa, sedangkan apabila anak mendapat pasangan yang mampu membimbing maka orang tua akan merasa tenang karena mengetahui sifat dari orang yang akan dijodohkan dengan anaknya. Seperti yang diungkapkan oleh salah satu tetua di kampung madura.
"yo ncen wong tuo ndek kene iki pokok ngerti bendino e ngono lo ndok, lek adoh-adoh iku yo wedi soal e gak ngerti bendinane. Lek ndek 


kene mulai bendinane sampe
keturunan e sopo kan ngerti"
(W.AJ.19)

(iya memang orang tua di kampung madura ini yang terpenting mengerti kesehariannya, kalau dapat jodoh orang luar kampung yang jauh takut karena tidak mengetahui kesehariannya. Kalau sama-sama dari kampung madura mulai dari keseharian sampai dengan keturunannya siapa diketahui)

"asli e seng di wedeni ambek wong meduro iku lak sak wis e mati iku a nduk, lek oleh e wong adoh iyo lek genah lek pas enggak iku wedi lek pas mati gak ono seng dungakno (do;a) no" (W.AJ.19)

(sebetulnya yang di takuti oleh orang kampung madura yaitu setelah kematiannya, kalau anaknya mendapat jodoh yang jauh dari rumah iya kalau mengerti tindakan apa yang harus dilakukan [kebudayaan, agama] kalau tidak mengerti kita sebagai orang tua tidak akan mendapat kiriman do’a)

Alasan lain tradisi perjodohan itu sendiri dilakukan karena kurangnya pengetahuan orang tua terhadap hakikat sebuah perkawinan itu sendiri. Mereka beranggapan bahwa perkawinan seorang anak sudah menjadi tanggung jawab dan hak orang tua.

"meskipun ngono wong tuo yo tetep duwe hak gawe rabino anak e" (W.AJ.16)

(meskipun begitu orang tua juga memiliki hak untuk ikut campur dalam urusan menikahkan anaknya)

Ekonomi yang mapan juga menjadi ukuran bagi sebagian masyarakat kampung Madura. Biasanya perkawinan semacam ini dilakukan karena keluarga tidak ingin harta yang dimiliki jatuh ke tangan orang lain, orang tua akan memilih menjodohkan dengan keluarga sendiri meski hubungannya begitu dekat. Hal ini hanya dilakukan oleh orangorang tertentu seperti yang disampaikan oleh salah satu tetua dalam proses wawancara

"oh lek keluarga e iku ancen nduk gak pingin dunyo e metu nang uwong. Ancen gak kabeh ndek kene seng koyok ngono.. yo ono seng ngono tapi iku seng wong soge.. lek seng wong biasa yo gak nduk pokok inti ne ngerti bendinane agama e, sembayang e, yo kerjo e temen". (W.AJ.18)

(oh, kalau keluarga itu [salah satu keluarga di kampung madura] memang tidak ingin harta yang dimiliki jatuh ke tangan orang lain. Memang tidak semua masyarakat kampung madura disini seperti itu.. ada memang yang seperti itu tetapi rata-rata orang yang kaya.. kalau orang yang biasa ya tidak karena yang dinilai yaitu dari kesehariannya, agamanya, sholat nya, pekerjaannya.. bukan semata-mata harta nya)

Pengaruh lingkungan sosial untuk merubah pribadi agar sama dengan kondisi lingkungan yang ada juga menjadi penyebab terjadinya perjodohan, seperti yang disampaikan oleh salah satu tetua di kampung madura bahwa sistem perjodohan ada sejak zaman dahulu hingga sampai saat ini

"iyo nduk akeh-akeh e ngono yo wes jaman biyen iku oleh e asli kene. Kan ngono iku di jodohno nduk ambek wong tua. jaman siti nurbaya yo nduk ya...” (W.AJ.14)

(iya nak rata-rata bagitu mulai zaman dahulu yang menikah rata-rata jodohnya juga asli sini. Karena di 
jodohkan nak sama orang tua. zaman nya siti nurbaya ya nak)

Hal tersebut menjadikan seluruh masyarakatnya tanpa sadar mengikuti kebudayaan yang terjadi di Kampung Madura. Selain itu, putusnya pendidikan juga menjadi salah satu sebab orang tua menikahkan anak dengan sistem perjodohan. Pendidikan merupakan pijakan yang paling penting bagi setiap orang, terutama bagi generasi penerus bangsa. Orang tua di kampung madura sudah begitu mengerti tentang seberapa pentingnya pendidikan, namun bagi anak yang menolak untuk melanjutkan sekolah maka salah satu pilihan lain bagi orang tua yaitu menikahkan anaknya. Hal ini menjadi salah satu faktor tetap di berlakukannya sistem porjodohan di kampung madura. Seperti yang di katakan oleh subyek F.N dalam wawancara

\section{"iyo mulakne gak gelem di pondok no yo wes rabi ae, ambekne di kongkon mbalek nang pondok gak gelem yo wes rabi ae" (W.FN.14) \\ (iya karena tidak mau di pondok kan makanya dinikahkan, disuruh kembali ke pondok saja tidak mau ya sudah dinikahkan saja)}

Artinya masyarakat di kampung madura mengawinkan anak dengan sitem perjodohan dikarenakan beberapa sebab antara lain keinginan orang tua, status ekonomi, serta putusnya pendidikan di kampung tersebut. Meski kebanyakan orang tua menganggap mengawinkan anak dengan sistem perjodohan bertujuan agar anaknya hidup bahagia saat hidup berumah tangga, namun mereka tidak memahami bagaimana perasaan dan kondisi psikologis anak ketika dijodohkan.
Proses penyesuaian diri pada pasangan yang dijodohkan berbeda-beda, jangka waktu dalam menyesuaikan diri tiap individu pun juga berbeda-beda. Berdasarkan data di lapangan penyesuaian diri pada pihak mempelai pria membutuhkan waktu yang cukup singkat dari pada pihak mempelai wanita. Jadi, diperlukan waktu yang lebih lama bagi wanita dalam menyesuaiakan diri dibanding laki-laki. Dengan diberikannya waktu yang lebih lama wanita akan mencoba memahami perilaku, sifat, dan watak pasangannya kemudian waktu tersebut merupakan kesempatan bagi pihak laki-laki untuk memberikan kasih sayang dan perhatian lebih untuk meluluhkan hati wanita. Dengan cara seperti itu, proses penyesuaian diri pada wanita akan berjalan dengan baik. Dalam proses penyesuaian diri yang terlibat bukan hanya pada kedua belah pihak saja, akan tetapi keluarga dan lingkungan juga turut andil dalam proses penyesuaian diri.

Hal ini sejalan dengan penelitian Ali (2010) bahwa proses penyesuaian diri melalui tiga unsur, di antaranya motivasi yang diibaratkan emosi dan kekuatan internal individu yang berpengaruh besar terhadap penyesuaian diri, yang kedua sikap individu terhadap realita juga akan berpengaruh terhadap proses penyesuaian diri, dan yang terakhir prinsip individu dalam menyesuaikan diri guna mencapai tujuan. Tiga proses tersebut dilakukan oleh pasangan perjodohan di Kampung Madura dalam melaksanakan proses penyesuaian diri.

Cara yang dilakukan oleh pasangan tersebut agar berhasil menyesuaikan diri yaitu tetap menjalin komunikasi yang baik, terbuka, saling menghargai, menjaga perasaan pasangan, menghormati dan berdiskusi untuk 
menyelesaikan permasalahan yang dihadapi dan akhirnya pasangan tersebut berhasil menyesuaikan diri dengan baik. Hal tersebut sejalan dengan penelitian Yani (2018) dalam mewujudkan keluarga yang harmonis dibutuhkan proses penyesuaian diri, yaitu dengan cara saling pengertian, memupuk rasa cinta, saling menerima kenyataan, musyawarah, dan saling memaafkan. Dengan begitu pasangan yang awalnya tidak saling mengenal akan mengenal dan memahami satu sama lain. Hartuti (2015) menjelaskan bahwa semakin dekat seseorang dengan suatu hal, semakin besar pula minat terhadapnya.

\section{Faktor Penjaga Keutuhan Rumah Tangga}

Faktor yang menjadikan subyek tetap menjaga keutuhan rumah tangga dan awetnya sebuah pernikahan karena adanya tanggung jawab antara kedua belah pihak dalam menjalankan tugasnya sebagai suami dan istri. Selain itu komitmen dalam membentuk keluarga sakinah, mawaddah, warahmah sudah menjadi pijakan awal pasangan (W.S.7). Selain itu, orang tua juga menjadi faktor dalam menjaga keutuhan rumah tangga, subyek beranggapan dengan menuruti keinginan orang tua berarti akan menjadi kebanggaan tersendiri bagi orang tua. Kemudian menjadi acuan bagi subyek untuk terus mempetahankan hubungannya dengan adanya komitmen pada pasangan akan menjadikan pasangan yang dijodohkan mampu mempertahankan keutuhan rumah tangga yang dibangun.

"yo pertama e mikir, mikir disek.. mikir iku rong dino (dua hari) engkok aku lek emoh aku cek wegah e mbalek nang pondok, tapi lek gak di trimo iku yok opo.. kene kepingin banggakno wong tuo, yok opo carane.. yo terus aku langsung gelem iku... gelem di jodohno iku" (W.FN.23)

(ya pertamanya difikir dulu.. difikir itu selama dua hari, nanti ketika saya tidak mau saya di suruh kembali ke pondok, dan saya tidak ingin kembali ke pondok. Tetapi kalu diterima itu ya bagaimana.. saya ingin membanggakan orang tua bagaimana caranya.. ya kemudian saya langsung menerima untuk dijodohkan)

Sama halnya dengan penelitian Latifatunnikmah \& Lestari (2017) bentuk perilaku dalam menjaga komitmen diwujudkan dengan sikap bertanggung jawab, saling percaya, saling memahami, menghargai serta taat terhadap ajaran agama juga memegang peran penting, namun yang berbeda adalah komitmen yang dibangun, dalam penelitian ini komitmen terbangun setelah pernikahan diselenggarakan, sedangkan dalam (Latifatunnikmah \&Lestari, 2017) komitmen telah dibangun sebelum menikah, yaitu mulai dari tahap ketertarikan sampai kesepakatan dalam melaksanakan pernikahan.

\section{Pengendalian Konflik pada Pasangan Perjodohan}

Dalam kehidupan rumah tangga setiap individu tidak terlepas dari permasalahanpermasalahan yang datang, baik bersifat sepele atau pun masalah yang bersifat besar. Begitu pun pasangan di Kampung Madura meski dari awal pernikahan kedua belah pihak dengan sistem perjodohan namun keduanya mampu meminimalisir masalah tersebut dengan cara beragam. Salah satunya tetap terjalinnya komunikasi dan mencari solusi permasalahan dengan baik.

"yo seng sabar, yo omong-omongan opo iki kok ngene-ngene, salah e iki 
opo ko moro meneng-meneg an ayo iki di omongno jeneng $e$ wong wes berkeluarga, isin ojo ngono. Dadi yo diskusi bareng solusine yok opo" (W.FN.48)

(iya yang sabar, saling komunikasi misal ada masalah kenapa ini kok begini, salahnya apa ko tiba-tiba saling diam, ayo dibicarakan kita sudah berkeluarga, malu jangan begitu. Jadi ya di diskusikan barengbareng solusinya bagaimana)

Strategi coping atau pengendalian konflik pada subyek terlihat dari kebiasaan sehari-hari subyek yang menjadikan masyarakat sekitarnya sebagai tolok ukur dalam memiliki sesuatu. Meminta dibelikan gelang emas kepada suami seperti milik tetangganya dan gaya meminta seperti anak kecil yang tidak bisa dijanjikan (disemayani). Hal seperti itu terjadi lagi saat istri meminta dibelikan sandal seperti kakak keponakan, kemudian suami juga menuruti kemauan istri tanpa ada pertimbangan lebih lanjut (data observasi 22/11/18). Hal tersebut sering peneliti temui selama melakukan observasi di sana, namun hubungan masyarakat di kampung Madura sangat harmonis.

Dalam teori hirarki kebutuhan Abraham Maslow dijelaskan bahwa ada lima tingkatan kebutuhan dasar, yaitu kebutuhan fisiologis, kebutuhan akan rasa aman, kebutuhan akan kasih sayang, kebutuhan akan penghargaan, dan kebutuhan akan aktualisasi diri (Feist, 2014). Maslow (dalam Fest, 2014) menjelaskan bahwa individu akan memuaskan kebutuhan dari tingkat dasar ke tingkat berikutnya, akan tetapi bila pada tingkatan kebutuhan belum terpenuhi atau belum terpuaskan maka akan kembali pada tingkatan sebelumnya. Berdasarkan kebutuhan tersebut, individu yang dijodohkan telah melewati fase pemenuhan kebutuhan fisologis, dan kebutuhan akan rasa aman, akan tetapi pada tingkat kebutuhan kasih sayang belumlah terpenuhi karena individu menikah tidak berdasarkan keinginan hati. Oleh karena itu, individu kembali pada pada kebutuhan rasa aman, akan tetapi pada kasus perjodohan individu akan merasa tidak ada yang berpihak kepadanya dan menjadikan kebutuhan akan rasa aman tidak terpenuhi dan kembali pada kebutuhan fisiologis. Dengan terpenuhinya kebutuhan fisiologis yang dipenuhi oleh pasangannya maka hirarki kebutuhan akan meningkat kembali.

\section{SIMPULAN}

Berdasarkan hasil penelitian menunjukkan disimpulkan bahwa perjodohan terjadi sudah menjadi tradisi dan dipicu karena kekhawatiran orang tua akan masa depan anaknya serta karena pendidikan. Penelitian juga menghasilkan Kematangan emosi dan persiapan merupakan faktor resiko dalam perjodohan. Konflik yang muncul sementara bisa di redam dengan memenuhi keinginan materi dari kedua belah pihak, selain tetap menjalin komunikasi antar keluarga. Dari hasil ini menyimpulkan bahwa peran masyarakat khususnya keluarga dalam menyiapkan mental calon mempelai dalam pernikahan yang dijodohkan. Kematangan emosi yang baik akan memunculkan kendali diri dan komitmen yang baik dalam pernikahan.

\section{DAFTAR PUSTAKA}

Afrida S.N \& Andromeda, A. (2017) Tipe komitmen perkawinan pada pasangan yang menikah dini di kabupaten Brebes. Intuisi: Jurnal Psikologi Ilmiah, 9 (2), 129-144. 
Ali, M. (2010). Psikologi remaja perkembangan peserta didik. Jakarta: PT Bumi Aksara.

Ardhianita, I. (2012). Kepuasan pernikahan ditinjau dari berpacaran dan tidak berpacaran. Jurnal Psikologi. 32 (2), 101111.

Creswell, J. W. (2015). Penelitian kualitatif dan desain riset. Yogyakarta: Pustaka Pelajar.

DeGenova, M. (2008). Intimate Relationships Marriages \& Families. New York: McGraw-Hill.

Dewanti, W. T. (2012). Perbedaan penyesuaian pernikahan pada suami dan isteri yang dijodohkan dengan yang tidak dijodohkan Universitas Bina Nusantara.

Eko, M. D. (2011). Psikologi sosial. Jakarta: Salemba Humanika.

Fadhilah, N. (2013). Faktor-faktor penyebab percaraian (studi terhadap perceraian yang terjadi di desa Bantur kab. Semarang). Skripsi Jurusan Syari'ah STAIN Salatiga.

Feist, J. F. (2014). Teori kepribadian. Jakarta: Salemba Humanika.

Hartuti, P. M. (2015). Peran Konsep Diri, Minat dan Kebiasaan Belajar. Jurnal Formatif 5(2):, 91-99.

Herdiansyah, H. (2015). Metodologi penelitian kualitatif untuk ilmu psikologi. Jakarta: Salemba Humanika.

Latifatunnikmah \& Lestari, S. (2017). Komitmen pernikahan pada pasangan suami istri bekerja. Humanitas, 14 (2) 103 119.

Meinarno, S. W. (2009). Psikologi Sosial. Jakarta: Salemba Humanika.

Moleong, L. J. (2007). Metodologi Pelitian Kualitatif. Bandung: Remaja Rosdakarya.
Nana, D. (2018, November 27). Perceraian di kabupaten malang di dominasi kaum hawa. Retrieved from Malang Times.com: https://www.malangtimes.com/baca/33579 /20181127/110700/perceraiandikabupaten-malang-masih-didominasikaum-hawa

Novitasari, D. W. (2013). Keterbukaan Pada Pasangan Arranged Married Mengenai Dimensi Passion Dalam Committed Romantic Relationships. Commonline Departemen Komunikasi. 4 (2) 134-147.

Nuqul, F. L. (2009). Perbedaan Penilaian Keadilan Karyawan ditinjau dari Jenis Kelamin. Egalita: Jurnal Kesetaraan dan Keadilan Gender, 4 (2) 207-216.

Setiawan, D. (2018). Dampak perkembangan tekhnologi informasi dan komunikasi terhadap budaya. Simbolika, 4 (1) 62-72.

Taylor, S. E. (2009). Psikologi sosial edisi ke dua belas. Jakarta: Kencana Prenada Media Group.

Yani, I. (2018). Harmonisasi keluarga pasangan suami istri yang tidak memiliki keturunan di desa bangun jaya kec. Tambusai utara kab. Rokan hulu. Jom Fisip, 1-14.

Yulianto, M. d. (2018, Januari Minggu). Ratusan Ribu Kasus Perceraian Terjadi dalam Setahun. Jakarta, Indonesia. 